\title{
Selective Recovery of Manganese from Anode Sludge Residue by Reductive Leaching
}

\author{
Toni Kauppinen ${ }^{1, * \mathbb{D}}$, Tuomas Vielma ${ }^{1}$, Justin Salminen ${ }^{2}$ and Ulla Lassi ${ }^{1}$ (D) \\ 1 Research Unit of Sustainable Chemistry, University of Oulu, P.O. Box 3000, FI-90570 Oulu, Finland; \\ tuomas.vielma@chydenius.fi (T.V.); ulla.lassi@oulu.fi (U.L.) \\ 2 Boliden Kokkola, Sinkkiaukio 1, FI-67100 Kokkola, Finland; justin.salminen@boliden.com \\ * Correspondence: toni.kauppinen@chydenius.fi; Tel.: +358-40-661-2941
}

Received: 26 March 2020; Accepted: 15 June 2020; Published: 17 June 2020

\begin{abstract}
Manganese-containing anode sludge is a common side-product in the electrowinning of zinc. The anode sludge consists mainly of oxidized manganese, but also lesser amounts of lead, calcium, and other minor metals. The impurities present in the anode sludge mandate new recycling strategies for its efficient use. This work demonstrates a novel method for selective manganese recovery from lead- and calcium-bearing manganese oxide solid residue. Leaching with sulfuric acid in the presence of a selected reducing agent, such as hydrogen peroxide or citric acid, yields a concentrated $\mathrm{MnSO}_{4}$ solution with high selectivity over calcium and lead. Manganese yields up to $98 \%$ can be obtained. Minimization of calcium and lead in final manganese product can be accomplished with the correct choice of leaching conditions. Alongside manganese sulfate solution, leaching residue with high content of lead and silver was also formed.
\end{abstract}

Keywords: recycling; manganese; reductive leaching; anode sludge; impurity control

\section{Introduction}

Manganese is the 12th most abundant element in Earth's crust, but utilizable resources are unevenly distributed [1-3]. South Africa has the largest reserves and it is producing most of the world's manganese. Main uses for manganese are steel production, non-ferrous metallurgy, batteries, dietary additives, and fertilizers [2]. The amount of high-grade ores has been diminishing, making low-grade and secondary resources more important in the future [4]. One potential secondary manganese source is the anode sludge formed during zinc electrolysis [5].

EU Waste Directive [6] and corresponding national legislation in Finland [7] aim to prevent waste and by-product formation and to promote the utilization of secondary resources. The potential re-use of anode sludge supports these intentions. The use of secondary resources and the aim to create a circular economy is very topical [6,7].

Divalent manganese is present in zinc electrowinning feed solution in order to preserve the surface of lead anodes from oxidative corrosion during the electrowinning process. Even a small concentration of manganese can increase the operation time of the lead anodes significantly [8,9]. Lead anodes can be also alloyed with small amounts of silver and calcium in order to further increase the corrosion resistance [8]. The corrosion of lead anodes results in the formation of lead sulfate (Equation (1)) and oxide (Equations (2) and (3)).

$$
\begin{gathered}
\mathrm{Pb}(\mathrm{s})+\mathrm{SO}_{4}{ }^{2-}(\mathrm{aq})=\mathrm{PbSO}_{4}(\mathrm{~s})+2 \mathrm{e}^{-} \mathrm{E}^{0}=0.361 \mathrm{~V} \\
\mathrm{~Pb}(\mathrm{~s})+2 \mathrm{H}_{2} \mathrm{O}=\mathrm{PbO}_{2}(\mathrm{~s})+4 \mathrm{H}^{+}(\mathrm{aq})+4 \mathrm{e}^{-} \mathrm{E}^{0}=0.610 \mathrm{~V} \\
\mathrm{PbSO}_{4}(\mathrm{~s})+2 \mathrm{H}_{2} \mathrm{O}=\mathrm{PbO}_{2}(\mathrm{~s})+2 \mathrm{H}^{+}(\mathrm{aq})+2 \mathrm{e}^{-}+\mathrm{H}_{2} \mathrm{SO}_{4}(\mathrm{aq}) \mathrm{E}^{0}=1.685 \mathrm{~V}
\end{gathered}
$$


Manganese oxidizes on the anode and in the bulk of the process solution, which leads to precipitation of different manganese oxides [9]. Amount of lead in the electrolyte solution is limited by adding water-soluble strontium compounds into the electrowinning cells $[8,10,11]$. Lead is incorporated into precipitating strontium sulfate crystals [10].

Precipitated oxidation products settle on the bottom of the electrolysis cells and form a mixture called anode sludge. Along with manganese and lead, anode sludge contains lesser amounts of calcium, zinc, strontium and sodium [8].

Anode sludge mostly contains tetravalent manganese, which has a limited solubility even in acidic conditions. Pyrometallurgical pre-treatment in elevated temperatures and the presence of a reducing agent are required to convert manganese to a readily dissolving state. Various reducing agents such as coal [12], graphite [13], carbon monoxide [14], various carbohydrates [15], sulfur dioxide [16], hydrogen [14], sulfur [17], and pyrite [18], have been reportedly tested. Reduction is followed by mineral acid leaching with sulfuric acid, nitric acid or hydrochloric acid [2]. These two steps can be carried out in one step introducing suitable reducing agent together with the mineral acid into the leaching solution [19].

The reduction of $\mathrm{MnO}_{2}$ in acidic media proceeds via steps given in Equations (4) and (5) [20-22]. The overall reaction and the corresponding standard reduction potential are given in Equation (6). In addition, various side-reactions and alternative steps have been proposed between different manganese species [22].

$$
\begin{gathered}
\mathrm{MnO}_{2}(\mathrm{~s})+\mathrm{H}^{+}(\mathrm{aq})+\mathrm{e}^{-} \rightarrow \mathrm{MnOOH}(\mathrm{s}) \\
\mathrm{MnOOH}(\mathrm{s})+3 \mathrm{H}^{+}(\mathrm{aq})+\mathrm{e}^{-} \rightarrow \mathrm{Mn}^{2+}(\mathrm{aq})+2 \mathrm{H}_{2} \mathrm{O} \\
\mathrm{MnO}_{2}(\mathrm{~s})+4 \mathrm{H}^{+}(\mathrm{aq})+2 \mathrm{e}^{-} \rightarrow \mathrm{Mn}^{2+}(\mathrm{aq})+2 \mathrm{H}_{2} \mathrm{O} \mathrm{E}^{0}=-1.28 \mathrm{~V}
\end{gathered}
$$

Reducing agents such as hydrogen peroxide [19,23-25], calcium sulfide [26], EDTA [27], ferrous ions [28], citric acid, oxalic acid, ascorbic acid, carbohydrates [29,30], sodium sulfide [31] and sulfur dioxide [32] have been reported in literature.

Manganese dioxide dissolves in sulfuric acid media by citric acid according to Equation (7) [29]. Although hydrogen peroxide is widely known as a strong oxidizing agent, it can act as reducing agent towards very strong oxidizing agents [23]. In sulfuric acid media, manganese dioxide dissolves by hydrogen peroxide reduction according to Equation (9) [19].

$$
\begin{gathered}
9 \mathrm{MnO}_{2}(\mathrm{~s})+9 \mathrm{H}_{2} \mathrm{SO}_{4}+\mathrm{C}_{6} \mathrm{H}_{8} \mathrm{O}_{7} \rightarrow 9 \mathrm{MnSO}_{4}+13 \mathrm{H}_{2} \mathrm{O}+6 \mathrm{CO}_{2} \\
\mathrm{O}_{2}+\mathrm{H}^{+}+\mathrm{e}^{-} \rightarrow \mathrm{H}_{2} \mathrm{O}_{2} \mathrm{E}_{0}=0.68 \mathrm{~V} \\
\mathrm{MnO}_{2}(\mathrm{~s})+\mathrm{H}_{2} \mathrm{O}_{2}+\mathrm{H}_{2} \mathrm{SO}_{4} \rightarrow \mathrm{MnSO}_{4}+2 \mathrm{H}_{2} \mathrm{O}+\mathrm{O}_{2}
\end{gathered}
$$

The aim of this study was to leach manganese selectively over calcium, lead and strontium from anode sludge by using sulfuric acid and a reducing agent. Citric acid and hydrogen peroxide were compared as possible reducing agents. The focus of this work was to determine the effect of leaching conditions on concentrations of sparingly soluble impurities present in anode sludge. Even though manganese has low economic value, the leaching process simultaneously concentrates lead and silver to leaching residue. Possible recovery of lead and silver increases viability of the process, alongside a reduction of landfill costs.

\section{Experimental Methods}

\subsection{Materials}

Real anode sludge from an operating zinc electrowinning process was used for this work. Excess solution was filtrated from anode sludge batch by vacuum filtration. Filtrated anode sludge was dried before use. Anode sludge sample was decomposed by microwave in presence of hydrochloric acid, 
nitric acid and tetra fluoroboric acid. Elemental analysis for anode sludge sample was measured with ICP-OES (Thermo Fisher). Table 1 shows the average chemical composition of dried anode sludge batch. Figure 1 shows the $\mathrm{X}$-ray powder diffraction pattern of the anode sludge sample as measured by PANalytical X'Pert Pro (Malvern, UK) using $\mathrm{Cu}-\mathrm{K} \alpha$ radiation. It can be seen that the anode sludge consists mainly of manganese dioxide and lead sulfate. Gypsum and strontium sulfate were also identified in the sample. Sulfuric acid (95.0-97.0\%, puriss, p.a., Sigma-Aldrich, St. Louis, MO, USA) was used as a leaching agent. Citric acid monohydrate (>99.5\%. ACS Reagent, Sigma-Aldrich) and $\mathrm{H}_{2} \mathrm{O}_{2}(30 \%$, puriss, p.a., Sigma-Aldrich) were used as reducing agents.

Table 1. Average chemical composition of the main elements in anode sludge.

\begin{tabular}{|c|c|c|c|c|c|}
\hline $\operatorname{Mn}(w t \%)$ & $\mathrm{Pb}(w t \%)$ & $\mathrm{Ca}(w \mathrm{t} \%)$ & $\mathrm{S}(w t \%)$ & Sr (wt $\%)$ & $\mathrm{Zn}(w t \%)$ \\
\hline 41.9 & 6.5 & 1.2 & 4.2 & 0.92 & 1.00 \\
\hline$K(w t \%)$ & $\operatorname{Mg}(w t \%)$ & $\mathrm{Na}(\mathrm{wt} \%)$ & $\mathrm{Fe}(w \mathrm{t} \%)$ & Al (wt\%) & Si $(w t \%)$ \\
\hline 1.4 & 0.17 & 0.21 & 0.015 & 0.04 & 0.23 \\
\hline
\end{tabular}

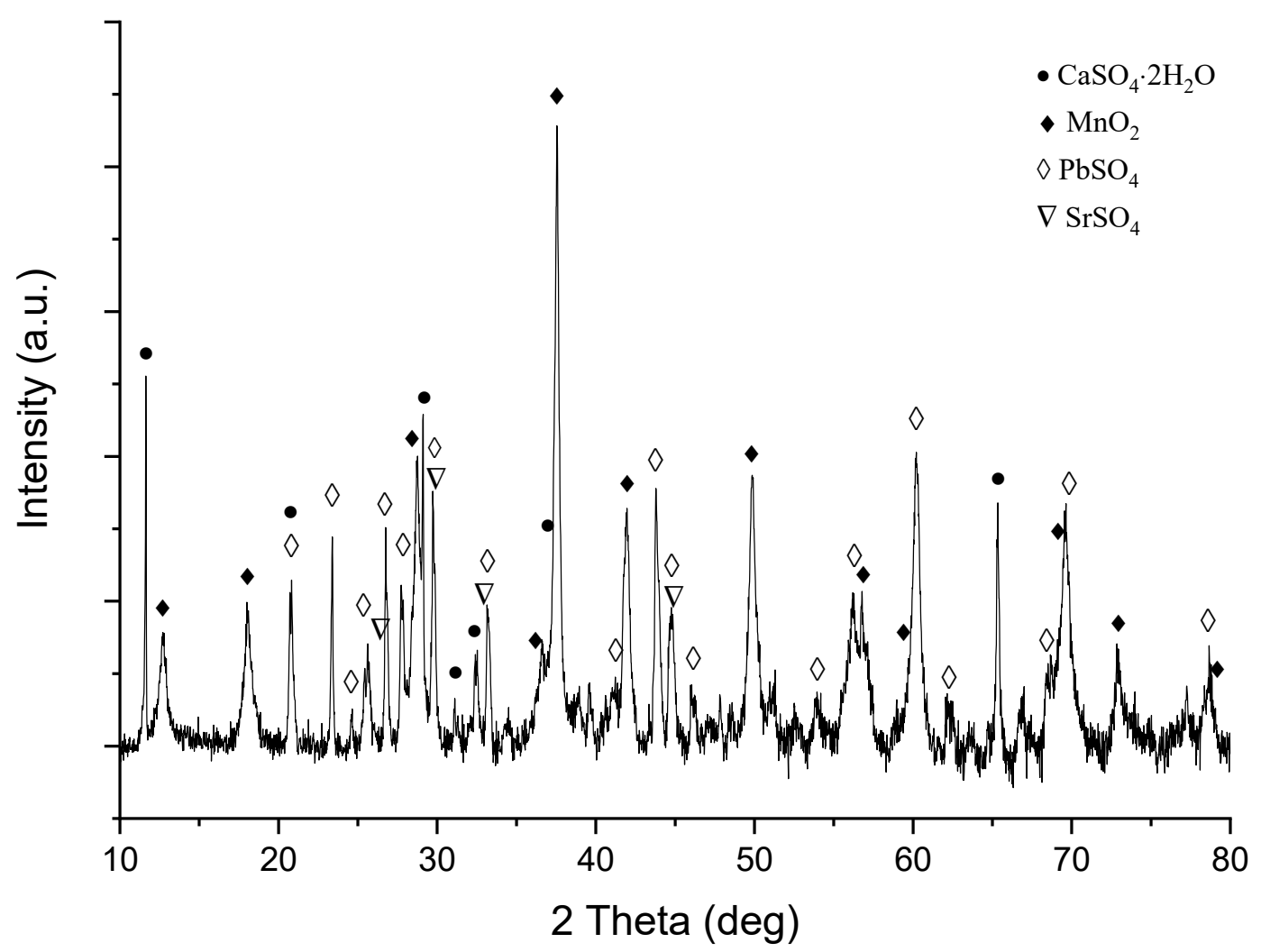

Figure 1. XRD pattern of anode sludge sample.

\subsection{Leaching Experiments}

The anode sludge was leached in a $1000 \mathrm{~mL}$ round-bottom flask. The reaction temperature was adjusted using a water bath on a hot plate. The evaporation of water was prevented by a reflux-condenser. The reaction mixture was magnetically stirred at a constant speed of $500 \mathrm{rpm}$. The anode sludge and the sulfuric acid diluted with water was added to the flask. The volume of the solution was adjusted so that the final volume of the reaction mixture after reducing agent addition was approximately $500 \mathrm{~mL}$ in each experiment.

Citric acid $(1.23 \mathrm{M})$ or hydrogen peroxide $(30 \%)$ were fed during first $30 \mathrm{~min}$ of reaction time by motorized pump (Watson-Marlow 520u). The reducing agents were fed over an extended period of time as both reactions are fast, exothermic, and lead to the formation of gases. Table 2 shows experimental 
parameters for each solid-to-liquid ratio used in leaching experiments. Citric acid experiments with $420 \mathrm{~g} / \mathrm{L}$ solid-to-liquid ratio were repeated using hydrogen peroxide as reducing agent.

Table 2. Experimental parameters for each solid-to-liquid ratio.

\begin{tabular}{ccccc}
\hline $\mathrm{S} / \mathrm{L}(\mathrm{g} / \mathrm{L})$ & Anode Sludge $(\mathbf{g})$ & $\mathbf{H}_{\mathbf{2}} \mathbf{S O}_{\mathbf{4}} \mathbf{( M )}$ & $\mathbf{H}_{\mathbf{2}} \mathbf{S O}_{\mathbf{4}} \mathbf{( m L )}$ & Reducing Agent $(\mathbf{m L})$ \\
\hline 420 & 210 & 5.18 & 332 & 168 \\
360 & 180 & 4.14 & 356 & 144 \\
300 & 150 & 3.22 & 380 & 120 \\
\hline
\end{tabular}

$5 \mathrm{~mL}$ samples were taken at predetermined intervals $(5,10,20,30,60,120$ and $180 \mathrm{~min})$. Each sample was filtered and quickly diluted with a dilute nitric acid solution, in order to prevent precipitation of sparingly soluble sulfates. After each experiment, the solid residue was recovered by filtration, washed, and dried. Residue solids were decomposed by microwave in presence of hydrochloric acid, nitric acid and tetra fluoroboric acid. All samples were analyzed with ICP-OES (Thermo Fisher, Waltham, MA, USA).

\section{Results and Discussion}

\subsection{Effect of Leaching Parameters on Manganese Concentration and Yield}

The stirring rate and stoichiometric ratios of chemicals (leaching agent and reducing agent) were kept constant during the set of experiments. The effects of temperature $\left(50,60,70\right.$, and $\left.80^{\circ} \mathrm{C}\right)$ and solid-to-liquid ratio $(320,360$, and $420 \mathrm{~g} / \mathrm{L}$ ) were examined. The volumes of each batch and reagent solution were adjusted to yield a final volume of $500 \mathrm{~mL}$.

Figures 2 and 3 show the effect of leaching time on manganese concentration at different temperatures with a constant solid-to-liquid ratio of $420 \mathrm{~g} / \mathrm{L}$ using citric acid and hydrogen peroxide as reducing agents. The results show that the effect of temperature on the leaching efficiency is not significantly different between temperatures 50 and $70{ }^{\circ} \mathrm{C}$. Most of the significant changes in manganese concentration happened during the first $30 \mathrm{~min}$ of the reaction, which is the feeding time of reducing agent. This indicates that the fed reducing agent reacted very quickly with manganese dioxide. Manganese concentrations ranging from 170 to $190 \mathrm{~g} / \mathrm{L}$ were obtained.

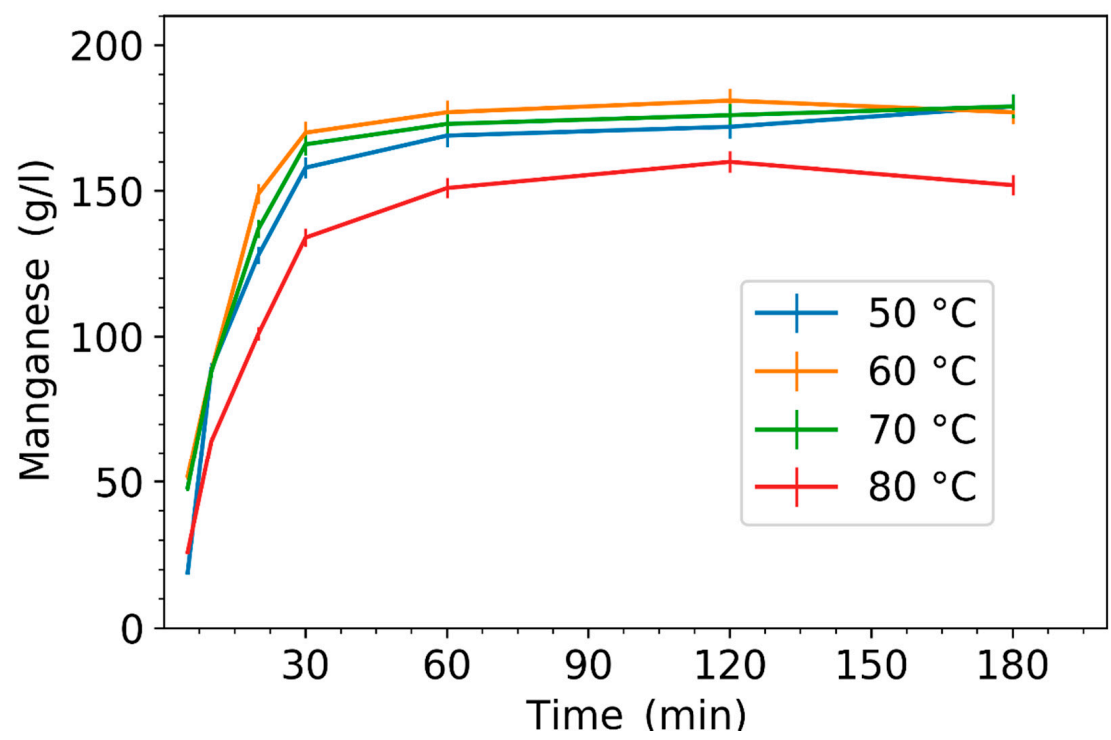

Figure 2. Manganese concentration as a function of time at 50, 60, 70 and $80{ }^{\circ} \mathrm{C}$ (solid-to-liquid (S/L) ratio $420 \mathrm{~g} / \mathrm{L}$, Citric acid). 


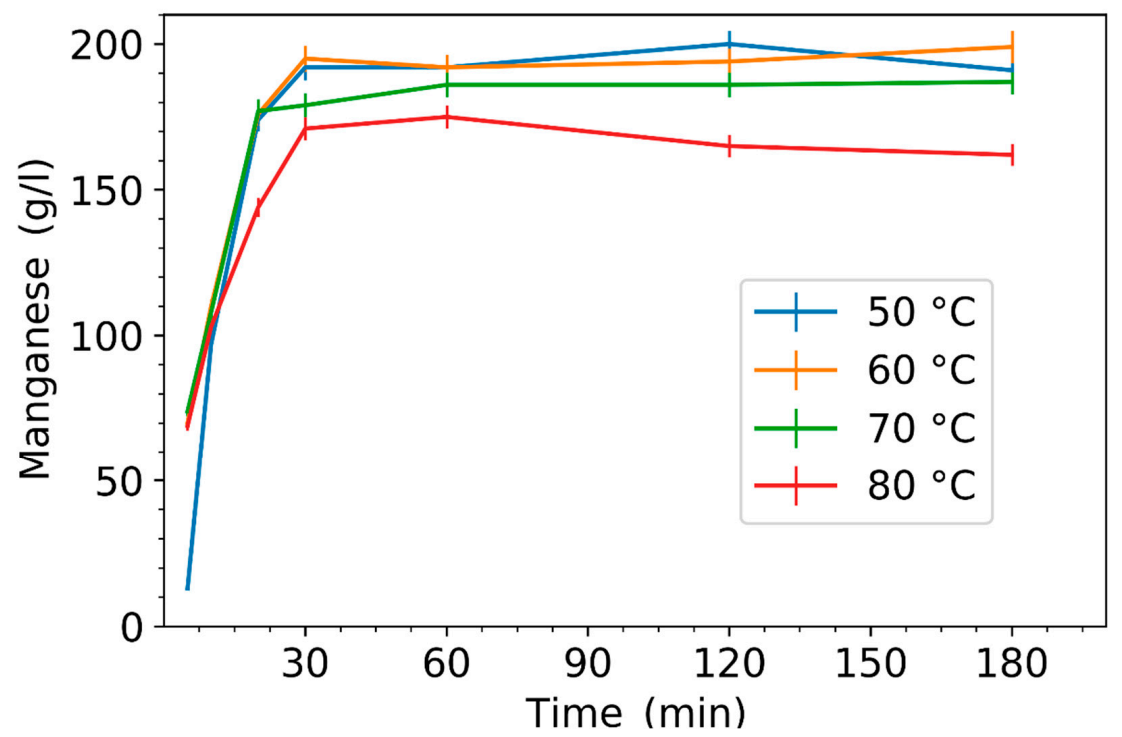

Figure 3. Manganese concentration as a function of time at $50,60,70$ and $80{ }^{\circ} \mathrm{C}\left(\mathrm{S} / \mathrm{L}\right.$ ratio $\left.420 \mathrm{~g} / \mathrm{L}, \mathrm{H}_{2} \mathrm{O}_{2}\right)$.

Experiments at 50 and $60^{\circ} \mathrm{C}$ produced quite similar leaching behaviors. At $80{ }^{\circ} \mathrm{C}$, the dissolution rate of manganese is the slowest and yield is lowest. During the first $30 \mathrm{~min}$, manganese dissolution is slower at $80^{\circ} \mathrm{C}$ probably due to partial thermal decomposition of reducing agents. At the later stages of leaching reaction, probably limitations in solubility of the manganese sulfate takes place. Figures 4 and 5 show the effect of leaching time on manganese yield at different temperatures with constant solid-to-liquid ratio of $420 \mathrm{~g} / \mathrm{L}$ using citric acid and hydrogen peroxide as reducing agents, respectively. All significant changes in manganese dissolution were observed during the first $30 \mathrm{~min}$ of reaction time.

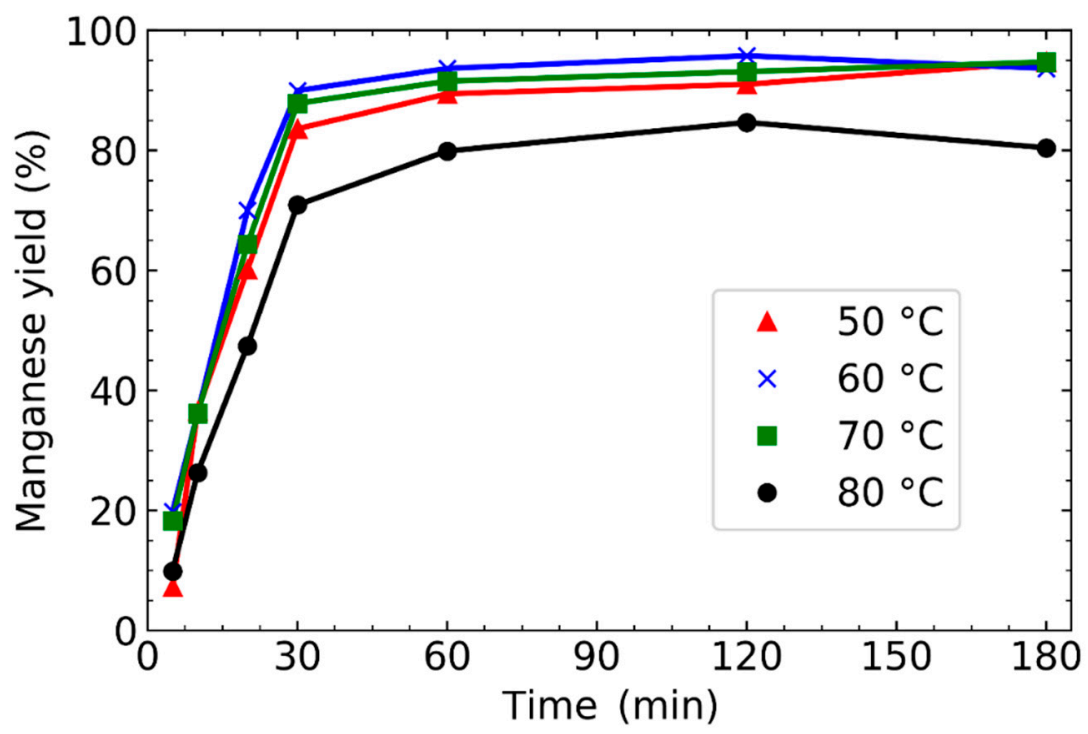

Figure 4. Manganese yield as a function of time at 50, 60, 70 and $80{ }^{\circ} \mathrm{C}(\mathrm{S} / \mathrm{L}$ ratio $420 \mathrm{~g} / \mathrm{L}$, Citric. acid).

Figure 6 compares manganese leaching efficiency between the two reducing agents, hydrogen peroxide and citric acid, at different temperatures while using a solid-to-liquid ratio of $420 \mathrm{~g} / \mathrm{L}$. The final concentrations of each leaching solution were used for comparison. The manganese concentration is approximately $6-7 \%$ higher when hydrogen peroxide was used as the reducing agent. Manganese dissolution kinetics are almost similar at 50 and $60^{\circ} \mathrm{C}$ when using citric acid as the reductant. While using hydrogen peroxide, 50 and $60^{\circ} \mathrm{C}$ give almost similar leaching kinetics. At $70{ }^{\circ} \mathrm{C}$ the leaching rate of manganese is almost as high as at 50 and $60^{\circ} \mathrm{C}$. Manganese dissolution slows down greatly at 
$80^{\circ} \mathrm{C}$ regardless of the choice of reducing agent. This limited manganese concentration is possibly due to the lowered solubility of manganese sulfate at $80{ }^{\circ} \mathrm{C}$ [33] or thermal decomposition or consumption of the reducing agent on side reactions.

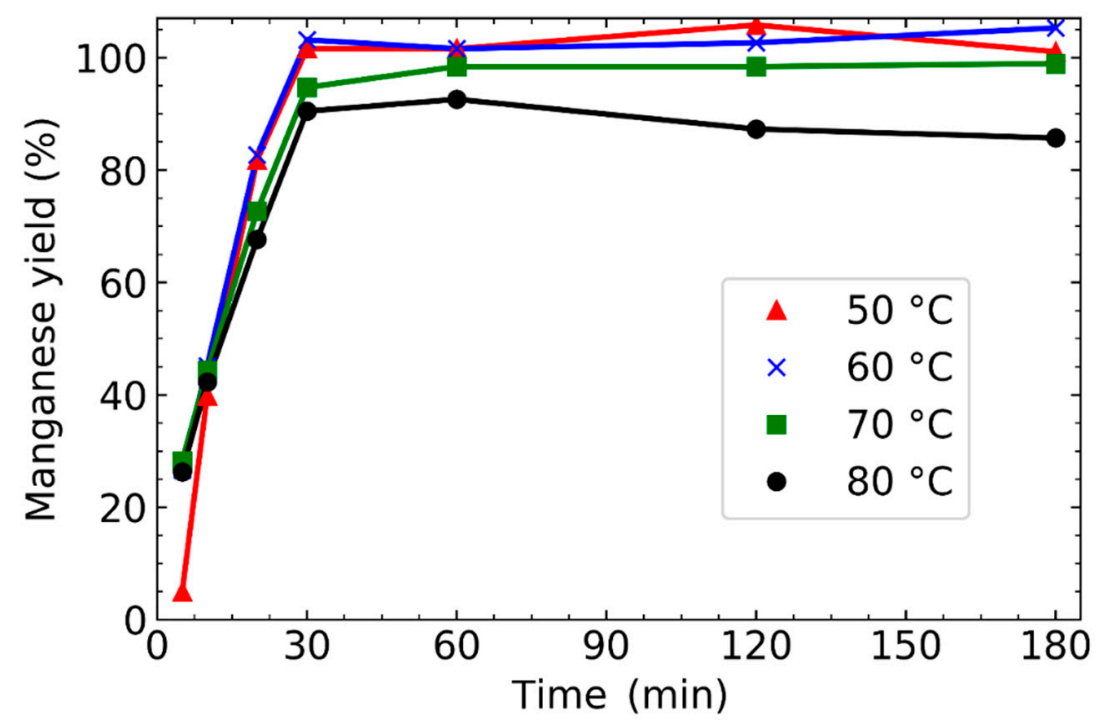

Figure 5. Manganese yield as a function of time at 50, 60, 70 and $80{ }^{\circ} \mathrm{C}\left(\mathrm{S} / \mathrm{L}\right.$ ratio $\left.420 \mathrm{~g} / \mathrm{L}, \mathrm{H}_{2} \mathrm{O}_{2}\right)$.

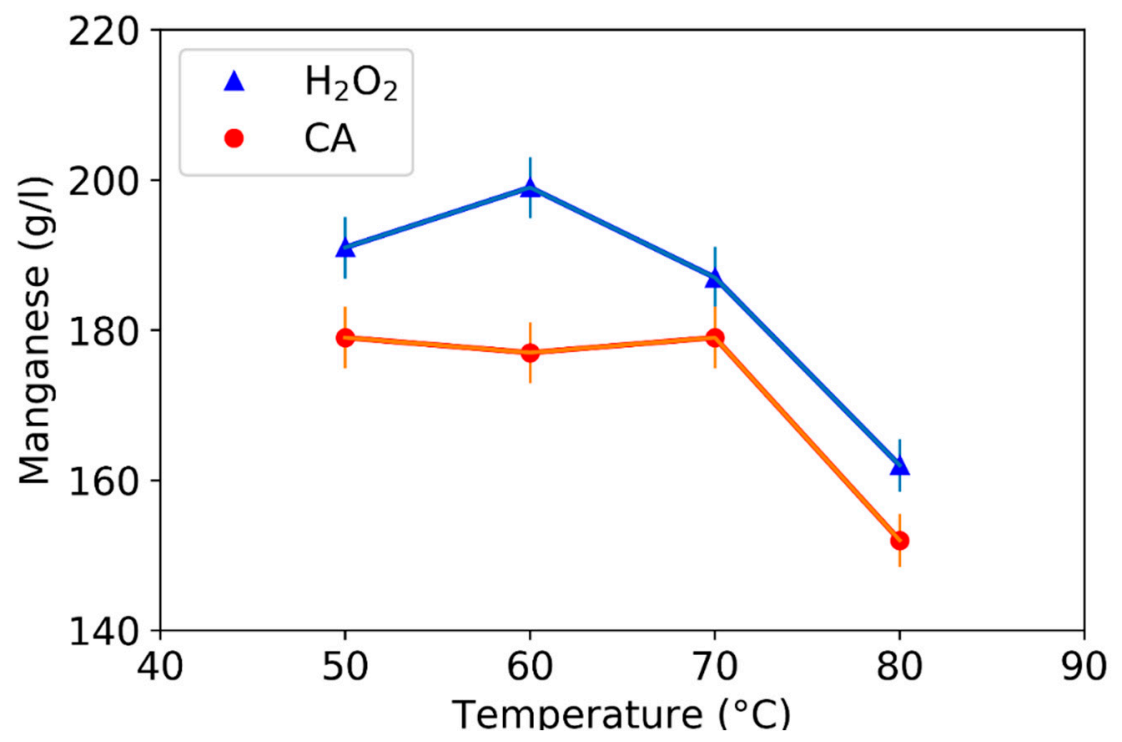

Figure 6. Comparison of reducing agents on manganese concentration at different temperatures after $180 \mathrm{~min}$ of reaction time using S/L 420 .

Figure 7 shows the effect of the solid-to-liquid ratio and reducing agent at $60^{\circ} \mathrm{C}$ on manganese concentration as a function of time. Manganese concentration was highest when $420 \mathrm{~g} / \mathrm{L}$ solid-to-liquid ratio was used. Using hydrogen peroxide as the reducing agent produced higher manganese concentrations than citric acid.

Figure 8 shows the effect of the leaching conditions on manganese yield. Yields have been calculated from washed solid leaching residues. On average, the highest yields were obtained at $60{ }^{\circ} \mathrm{C}$. Even though the highest concentrations were obtained from experiments with a solid-to-liquid $(\mathrm{S} / \mathrm{L})$ ratio of $420 \mathrm{~g} / \mathrm{L}$ using citric acid, these experiments had on average lower yields compared to experiment with lower S/L ratio. At $80^{\circ} \mathrm{C}$ and S/L $420 \mathrm{~g} / \mathrm{L}$ yields were higher than in yields calculated from liquid samples (Figures 4 and 5). This confirms that solid samples contained manganese sulfate, 
which dissolved during the washing. Hence manganese yields were lower due to crystallization of $\mathrm{MnSO}_{4}$ from supersaturated solution.

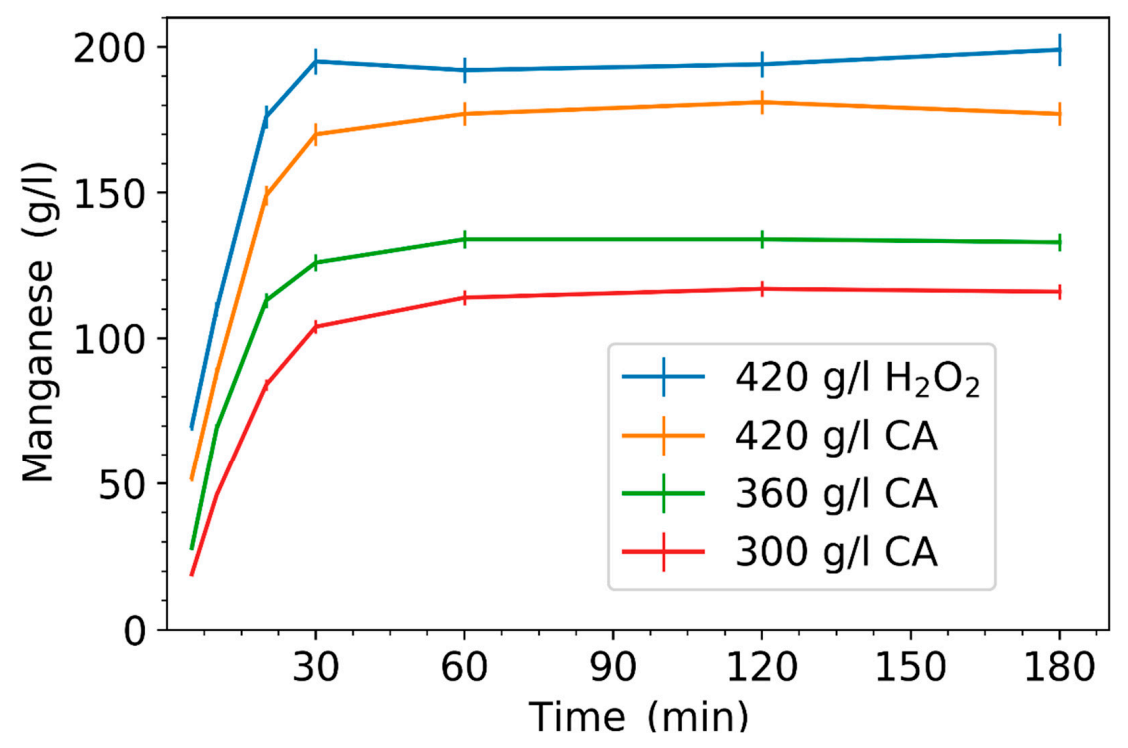

Figure 7. Effect of $\mathrm{S} / \mathrm{L}$ on manganese concentration as a function of time at $60^{\circ} \mathrm{C}$.

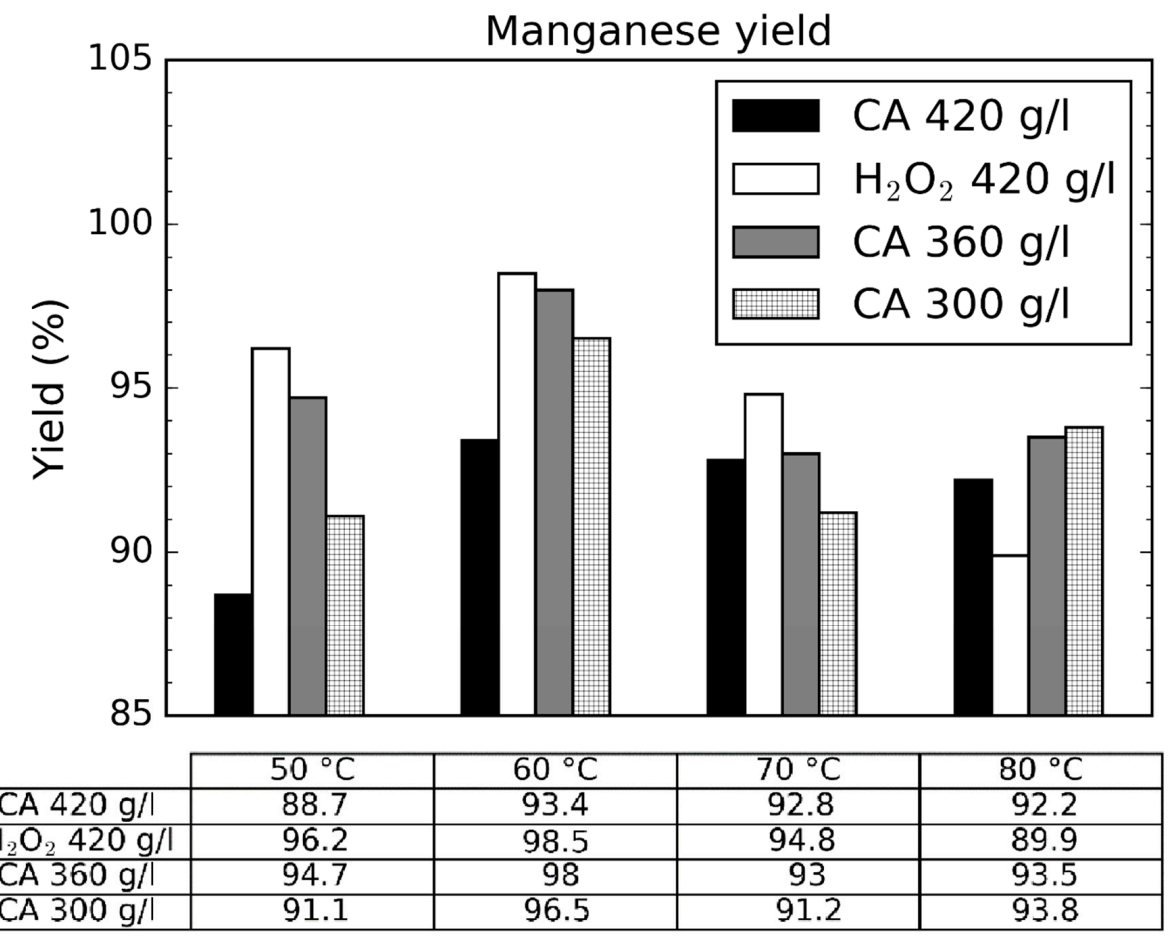

Figure 8. Effect of leaching conditions on manganese recovery rate after $180 \mathrm{~min}$ of reaction time.

\subsection{Effect of Leaching Parameters on Calcium and Lead Concentrations}

Solid-to-liquid ratio played an important role in the selectivity of manganese over lead, calcium and strontium. Figure 9 shows the effect of the solid-to-liquid ratio and temperature on the calcium $(\mathrm{g} / \mathrm{L})$ to manganese $(\mathrm{g} / \mathrm{L})$ ratio. On average solid-to-liquid ratio $420 \mathrm{~g} / \mathrm{L}$ improved selectivity of manganese over calcium versus lower solid-to-liquid ratios. Temperature changes between 50 and $70{ }^{\circ} \mathrm{C}$ do not seem to have clear pattern. At $80^{\circ} \mathrm{C} \mathrm{Ca} / \mathrm{Mn}$ ratio increases due to lowered manganese 
concentration as shown on Figure 6. This is probably a result of the lowered solubility of manganese at higher temperature.

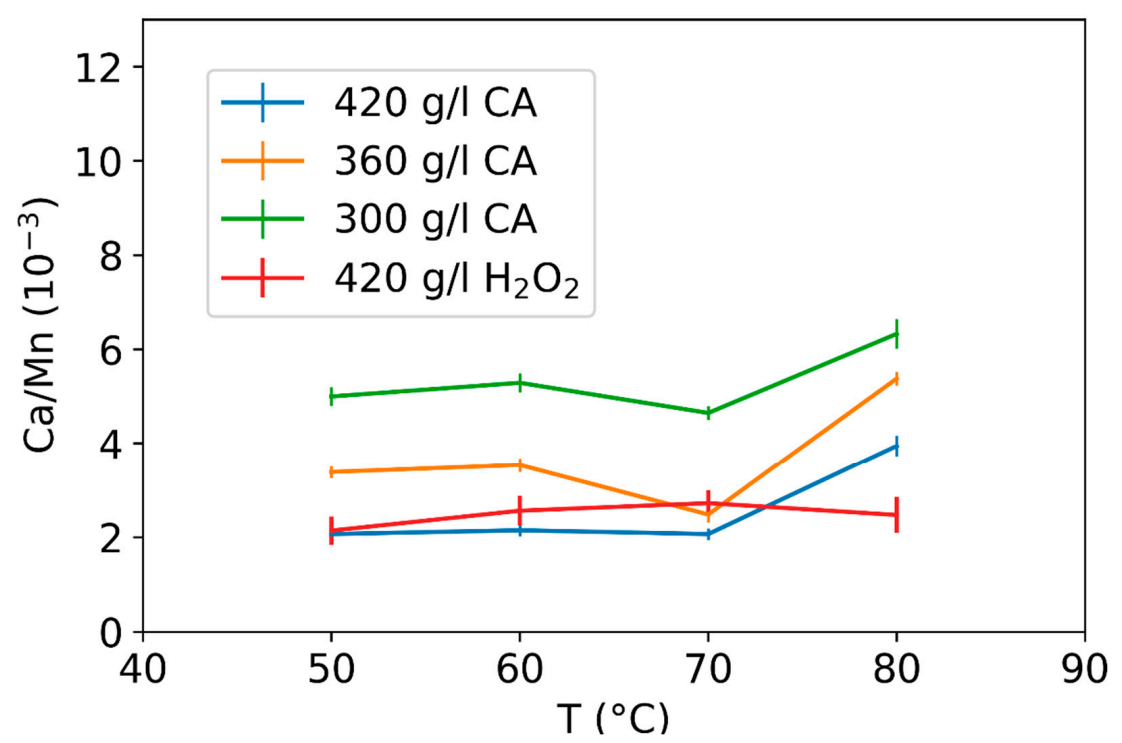

Figure 9. Effect of $\mathrm{S} / \mathrm{L}$ and temperature on calcium $(\mathrm{g} / \mathrm{L})$ to manganese $(\mathrm{g} / \mathrm{L})$ ratio after $180 \mathrm{~min}$ of reaction time.

Figure 10 shows the effect of the solid-to-liquid ratio and temperature on lead $(\mathrm{g} / \mathrm{L})$-to-manganese $(\mathrm{g} / \mathrm{L})$ ratio. By taking uncertainty into account, lead-to-manganese ratio does not show any obvious trend.

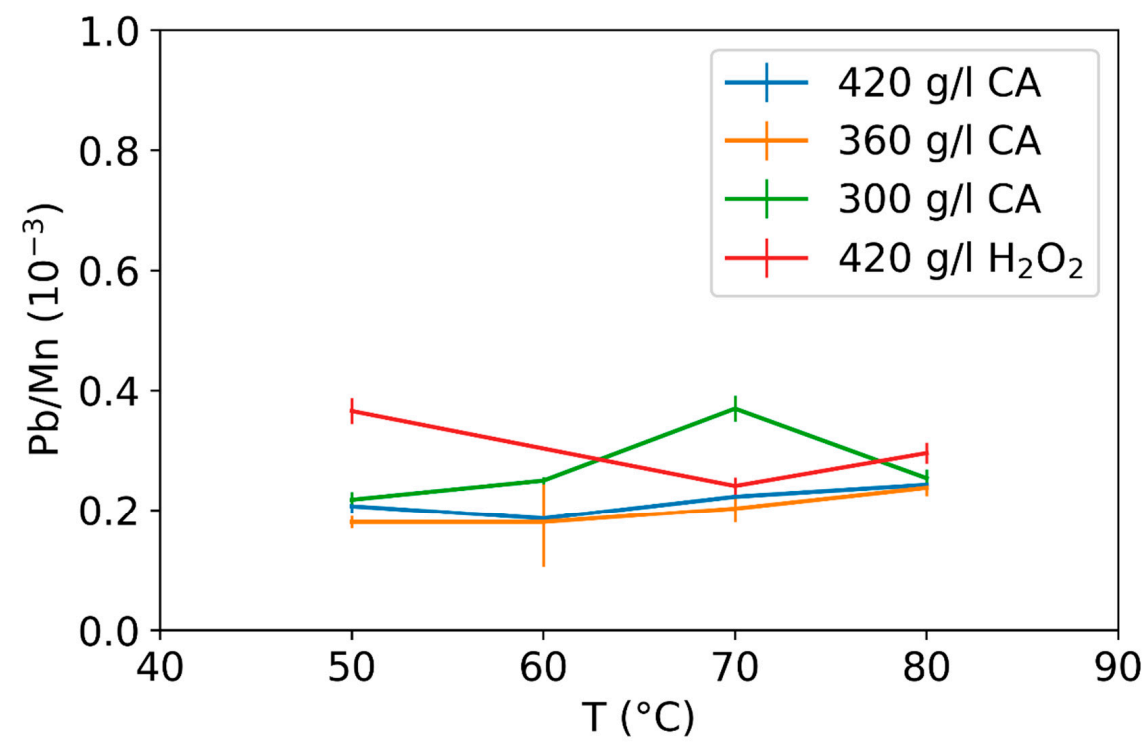

Figure 10. Effect of $\mathrm{S} / \mathrm{L}$ and temperature on lead $(\mathrm{g} / \mathrm{L})$ to manganese $(\mathrm{g} / \mathrm{L})$ ratio after $180 \mathrm{~min}$ of reaction time.

The effect of temperature on calcium concentration as a function of time using citric acid and hydrogen peroxide was examined. The data was obtained from experiments using a solid-to-liquid ratio $420 \mathrm{~g} / \mathrm{L}$, and citric acid as a reducing agent (Figure 11). The solubility reached its peak in the presence of citric acid after $5 \mathrm{~min}$ reaction time. It then steadily decreased and achieved a steady state after $60 \mathrm{~min}$. At $80^{\circ} \mathrm{C}$, the solubility was clearly higher than at lower temperatures. 


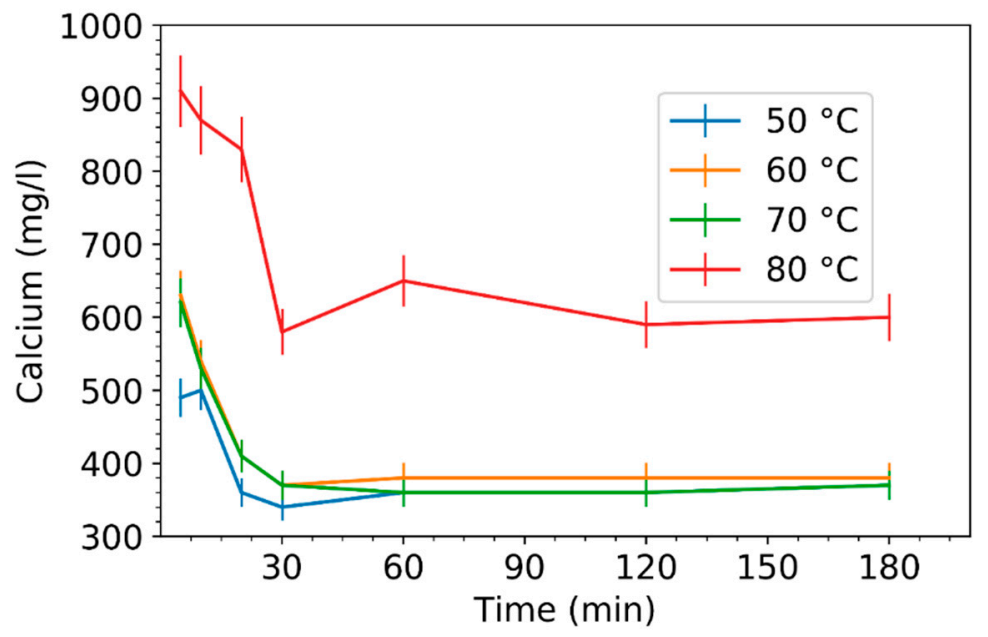

Figure 11. Calcium concentrations as a function of time at $420 \mathrm{~g} / \mathrm{L} \mathrm{S} / \mathrm{L}$ using citric acid as reducing agent.

Figure 12 shows calcium concentration as a function of time using hydrogen peroxide as reducing agent. Using hydrogen peroxide as the reducing agent produced low calcium concentrations in the beginning of the leaching reaction, whereas the citric acid experiments displayed the opposite result. Calcium concentrations increased at the beginning of the reaction, but after varying periods of time calcium concentration started to decrease to a level similar to what was observed in presence of citric acid. This difference in calcium leaching behavior is most likely connected to formation of different stable calcium-citrate complexes [34-36]. Complex formation leads to apparent increase in calcium sulfate solubility, which is seen as a large initial total calcium concentration. The concentration falls when the stabilizing citric acid is consumed in the leaching reaction.

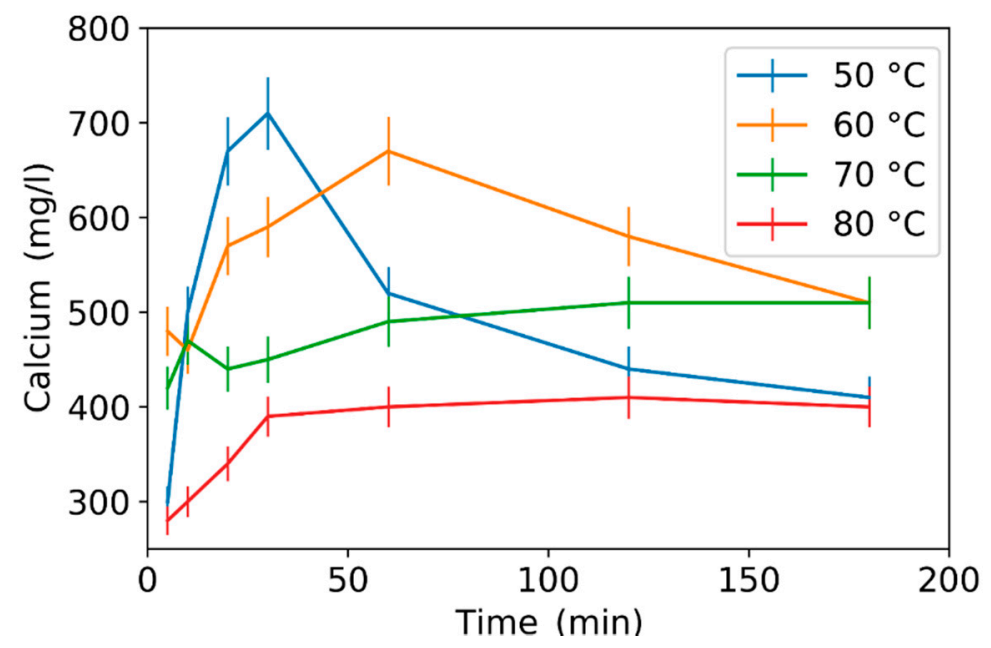

Figure 12. Calcium concentrations as a function of time at $420 \mathrm{~g} / \mathrm{L} \mathrm{S} / \mathrm{L}$ using hydrogen peroxide as reducing agent.

The biggest difference between the two reducing agents was that the calcium concentration initially decreased in the presence of citric acid and increased in the presence of hydrogen peroxide. Another difference was observed at $80^{\circ} \mathrm{C}$, where the calcium concentration was the highest when using citric acid and the lowest when using hydrogen peroxide.

\subsection{Purity of Leachate}

Table 3 shows the compositions of selected leachates obtained from leaching experiments. The leaching method used produced highly concentrated solutions of manganese sulfate. The most 
common impurities are zinc and potassium at approximately $4 \mathrm{~g} / \mathrm{L}$ concentrations at solid-to-liquid ratio $420 \mathrm{~g} / \mathrm{L}$. Lowering the solid-to-liquid ratio lowered concentration of zinc in the leachates. An additional purification step is required to remove zinc completely.

Table 3. Elemental analysis of the purity of leachates after reductive leaching.

\begin{tabular}{ccccccccc}
\hline & $\mathbf{M n}(\mathrm{g} / \mathrm{L})$ & $\mathbf{Z n}(\mathrm{g} / \mathrm{L})$ & $\mathbf{K}(\mathrm{g} / \mathrm{L})$ & $\mathbf{S}(\mathrm{g} / \mathbf{L})$ & $\begin{array}{c}\mathrm{Ca} \\
(\mathbf{m g} / \mathbf{L})\end{array}$ & $\begin{array}{c}\mathbf{P b} \\
(\mathbf{m g} / \mathbf{L})\end{array}$ & $\begin{array}{c}\mathbf{F e} \\
(\mathbf{m g} / \mathbf{L})\end{array}$ & $\begin{array}{c}\mathrm{Al} \\
(\mathbf{m g} / \mathbf{L})\end{array}$ \\
\hline $420 \mathrm{~g} / \mathrm{L}, 50^{\circ} \mathrm{C}, \mathrm{H}_{2} \mathrm{O}_{2}$ & 191 & 4.06 & 3.9 & 119 & 410 & 70 & 44 & 27 \\
$420 \mathrm{~g} / \mathrm{L}, 70^{\circ} \mathrm{C}, \mathrm{H}_{2} \mathrm{O}_{2}$ & 187 & 4.09 & 3.8 & 120 & 510 & 45 & 46 & 60 \\
$420 \mathrm{~g} / \mathrm{L}, 70^{\circ} \mathrm{C}, \mathrm{CA}$ & 179 & 4.09 & 3.7 & 107 & 370 & 40 & 44 & 27 \\
$360 \mathrm{~g} / \mathrm{L}, 50^{\circ} \mathrm{C}, \mathrm{CA}$ & 139 & 4.05 & 2.6 & 93 & 470 & 25 & 41 & 11 \\
$300 \mathrm{~g} / \mathrm{L}, 50^{\circ} \mathrm{C}, \mathrm{CA}$ & 116 & 3.07 & 2.2 & 79 & 620 & 29 & 30 & 13 \\
\hline
\end{tabular}

Other significant impurities in the filtrates were sodium and calcium. Sodium concentrations were dependent on the solid-to-liquid ratio. The leaching conditions can be used for limiting calcium concentration in leachates. With the choice of proper conditions, the calcium concentration could be limited to around $400 \mathrm{mg} / \mathrm{L}$, while the manganese concentration was closer to $200 \mathrm{~g} / \mathrm{L}$.

Table 4 shows legislative limit values for heavy metals in fertilizing products in Finland. Based on these limit values, the only troublesome impurity in manganese solution is lead. Zinc is acceptable, if soil analysis indicates a zinc deficiency. The amount of solid substance per liter was calculated from manganese and zinc concentrations. It was also presumed that solid substance would contain a stoichiometric amount of sulfate. The lead concentration per solid substance was calculated according to this assumption. From the solutions presented in Table 3, the lead concentration exceeded limits only in hydrogen peroxide experiments performed at $80{ }^{\circ} \mathrm{C}$. A solution produced at $80^{\circ} \mathrm{C}$ is still acceptable for forest fertilization.

Table 4. Limit values for heavy metals according to the Fertilizer Product Decree 24/2011 (Finnish Ministry of Agriculture and Forestry). Limit for copper and zinc can be exceeded if soil analysis indicates deficiency.

\begin{tabular}{ccccccccc}
\hline & $\begin{array}{c}\mathrm{As} \\
(\mathbf{m g} / \mathbf{k g})\end{array}$ & $\begin{array}{c}\mathbf{H g} \\
(\mathbf{m g} / \mathbf{k g})\end{array}$ & $\begin{array}{c}\mathrm{Cd} \\
(\mathbf{m g} / \mathbf{k g})\end{array}$ & $\begin{array}{c}\mathrm{Cr} \\
(\mathbf{m g} / \mathbf{k g})\end{array}$ & $\begin{array}{c}\mathrm{Cu} \\
(\mathbf{m g} / \mathbf{k g})\end{array}$ & $\begin{array}{c}\mathbf{P b} \\
(\mathbf{m g} / \mathbf{k g})\end{array}$ & $\begin{array}{c}\mathbf{N i} \\
(\mathbf{m g} / \mathbf{k g})\end{array}$ & $\begin{array}{c}\mathbf{Z n} \\
(\mathbf{m g} / \mathbf{k g})\end{array}$ \\
\hline Field & 25 & 1 & 2.5 & 300 & 600 & 100 & 100 & 1500 \\
Forest & 40 & 1 & 2.5 & 300 & 700 & 150 & 150 & 4500 \\
This & - & - & - & - & 1.44 & 76 & - & 9314 \\
work & - & & & & & & & \\
\hline
\end{tabular}

\subsection{Leaching Residue}

The obtained leaching residue had significant lead content along with manganese and calcium. Lead content in leaching residues varied from 24 to $28 \mathrm{wt} \%$. Manganese composition in leaching residues was on average $12 \mathrm{wt} \%$. With the correct choice of leaching conditions residual manganese could be lowered to as low as $3 \mathrm{wt} \%$, which corresponds to a leaching yield of $99 \%$. The calcium content of leaching residue varied from 5 to $11 \mathrm{wt} \%$. The leaching residue also contains a significant amount of silver (0.1-0.15 wt\%). XRD diagram of leaching residue sample, Figure 13, showed that calcium, lead and strontium formed sulfates during the leaching process. 


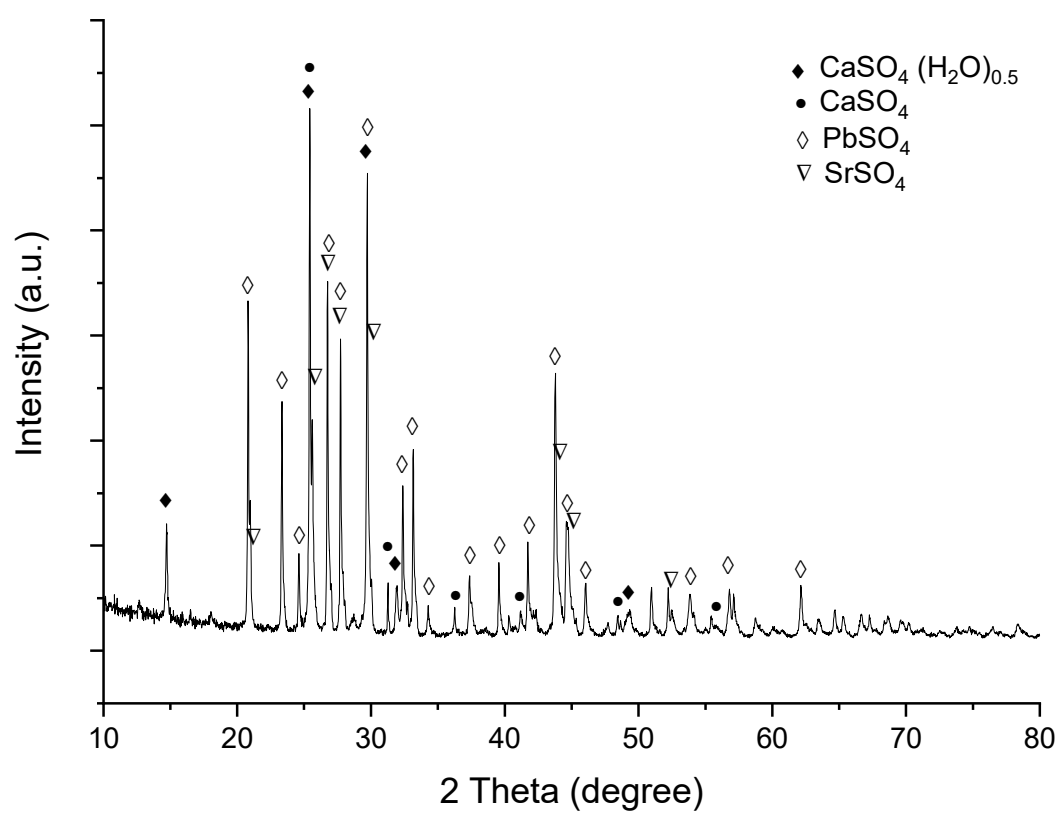

Figure 13. XRD pattern of leaching residue.

\section{Conclusions}

Manganese is a significant but often underappreciated raw material for ferrous/non-ferrous industry, batteries and fertilizers. In this study selective leaching of manganese from anode sludge was investigated as a single-step process.

Based on the results, concentrated manganese sulfate solution could be obtained from anode sludge with reductive leaching. Careful selection of leaching parameters can be used for lowering ratios of calcium and lead compared to manganese concentration. Using hydrogen peroxide as the reducing agent and $60{ }^{\circ} \mathrm{C}$ as reaction temperature favors the manganese concentration. A $98.5 \%$ leaching efficiency of manganese was achieved using hydrogen peroxide as a reducing agent at $60^{\circ} \mathrm{C}$. Lower yields were obtained at $420 \mathrm{~g} / \mathrm{L}$ solid-to-liquid ratio when citric acid was used as a reducing agent. Lowering the solid-to-liquid ratio improved manganese yields when citric acid was used as a reducing agent. Calcium content in the filtrate can be limited to approximately $400 \mathrm{mg} / \mathrm{L}$ regardless of reducing agent. The resulting leaching solution still contains approximately $5 \mathrm{~g} / \mathrm{L}$ of zinc, which is acceptable, if the solution is used as a nutrient solution for plants. High lead and silver content of the leaching residue could make it an attractive raw material for lead smelter. In future work, methods to demonstrate the production of high purity manganese sulfate from anode sludge are worthy of investigation.

Author Contributions: Conceptualization, T.K. and T.V.; Experimental, T.K and T.V. writing—original draft preparation, T.K. and T.V.; writing-review and editing, U.L. and J.S.; supervision, U.L. and J.S.; funding acquisition, U.L. All authors have read and agreed to the published version of the manuscript.

Funding: This research was funded by Central Ostrobothnia Region, Saostus (A71944), Tekes, AdChem (1792/31/2016) and Business Finland, SYMMET (4236/31/2018).

Acknowledgments: Tao Hu is acknowledged for kind help with XRD analyses.

Conflicts of Interest: The authors declare no conflict of interest.

\section{References}

1. Pakarinen, J. Recovery and Refining of Manganese as By-Product from Hydrometallurgical Processes. Ph.D. Thesis, Lappeenranta University of Technology, Lappeenranta, Finland, 28 October 2011.

2. Zhang, W.; Cheng, C.Y. Manganese metallurgy review. Part I: Leaching of ores/secondary materials and recovery of electrolytic/chemical manganese dioxide. Hydrometallurgy 2007, 89, 137-159. [CrossRef] 
3. Mineral Commodity Summaries 2016:, U.S. Geological Survey; Government Printing Office: Washington, DC, USA, 2016; 202p. [CrossRef]

4. Zhang, X.; Liu, Z.; Wu, X.; Du, J.; Tao, C. Electric field enhancement in leaching of manganese from low-grade manganese dioxide ore: Kinetics and mechanism study. J. Electroanal. Chem. 2017, 788, 165-174. [CrossRef]

5. Chandra, N.; Amritphale, S.S.; Pal, D. Manganese recovery from secondary resources: A green process for carbothermal reduction and leaching of manganese bearing hazardous waste. J. Hazard Mater. 2011, 186, 293-299. [CrossRef] [PubMed]

6. European Commission. Directive 2008/98/EC of the European Parliament and of the Council of 19 November 2008 on Waste and Repealing Certain Directives. Off. J. Eur. Union 2008, 51, 3-30.

7. Finnish Ministry of the Environment. Waste Act 646/2011, Jätelaki 646/2011. 2016. Available online: http://www.finlex.fi/fi/laki/ajantasa/2011/20110646 (accessed on 3 March 2020). (In Finnish).

8. Sinclair, J.R. The Extractive Metallurgy of Zinc; Spectrum Series; Australasian Institute of Mining and Metallurgy: Melbourne, VIC, Australia, 2005; p. 13.

9. Aromaa, J.; Barker, M.H.; Lagerstedt, A.; Torkkeli, J.; Forsén, O. Evaluation of Lead Anodes and their Tendecy to Manganese Dioxide Deposition. In Proceedings of the European Metallurgical Conference EMC 2009, Clausthal-Zellerfeld, Germany, 28 June-1 July 2009.

10. Bratt, G.C.; Smith, W.N. The effects of strontium compounds and related materials in the electrolytic production of zinc. Electrochemistry 1965, 7, 939-948.

11. Morrison, R.M.; MacKinnon, D.J.; Uceda, D.A.; Warren, P.E.; Mouland, J.E. The effect of some trace metal impurities on the electrowinning of zinc from Kidd Creek electrolyte. Hydrometallurgy 1992, 29, 413-430. [CrossRef]

12. Mishra, D.; Srivastava, R.R.; Sahu, K.K.; Singh, T.B.; Jana, R.K. Leaching of roast-reduced manganese nodules in NH3-(NH4)2CO3 medium. Hydrometallurgy 2011, 109, 215-220. [CrossRef]

13. Welham, N.J. Activation of the carbothermic reduction of manganese ore. Int. J. Miner. Process. 2002, 69, 187-198. [CrossRef]

14. Paixao, J.M.M.; Amaral, J.C.; Memoria, L.E.; Freitas, L.R. Sulphation of Carajas manganese ore. Hydrometallurgy 1995, 39, 215-222. [CrossRef]

15. Cheng, Z.; Zhu, G.; Zhao, Y. Study in reduction-roast leaching manganese from low-grade manganese dioxide ores using cornstalk as reductant. Hydrometallurgy 2009, 96, 176-179. [CrossRef]

16. You, Z.; Li, G.; Zhang, Y.; Peng, Z.; Jiang, T. Extraction of manganese from iron rich MnO2 ores via selective sulfation roasting with $\mathrm{SO} 2$ followed by water leaching. Hydrometallurgy 2015, 156, 225-231. [CrossRef]

17. Zhang, Y.; You, Z.; Li, G.; Jiang, T. Manganese extraction by sulfur-based reduction roasting-acid leaching from low-grade manganese oxide ores. Hydrometallurgy 2013, 133, 126-132. [CrossRef]

18. Li, C.; He, L.; Li, S.; Wang, Z. A study on the preparation of manganese sulfate by co-calcining pyrolysite and pyrite. Chem. World 2000, 4, 66-69.

19. Nayl, A.A.; Ismail, I.M.; Aly, H.F. Recovery of pure $\mathrm{MnSO}_{4} \cdot \mathrm{H}_{2} \mathrm{O}$ by reductive leaching of manganese from pyrolusite ore by sulfuric acid and hydrogen peroxide. Int. J. Miner. Process. 2011, 100, 116-123. [CrossRef]

20. Rodrigues, S.; Munichndraiah, N.; Shukla, A.K. A cyclic voltammetric study of the kinetics and mechanism of electrodeposition of manganese dioxide. J. Appl. Electrochem. 1998, 28, 1235-1241. [CrossRef]

21. Petitpierre, J.-P.; Comninellis, C.; Plattner, E. Oxydation Du MnSO4 en dioxyde de manganese dans $\mathrm{H} 2 \mathrm{SO} 4$ 30\%. Electrochim. Acta 1990, 35, 281-287. [CrossRef]

22. Lee, J.A.; Maskell, W.C.; Tye, F.L. The electrochemical reduction of manganese dioxide in acidic solutions: Part I. J. Electroanal. Chem. 1977, 79, 79-104. [CrossRef]

23. El Hazek, M.N.; Lasheen, T.A.; Helal, A.S. Reductive leaching of manganese from low grade Sinai ore in $\mathrm{HCl}$ using $\mathrm{H} 2 \mathrm{O} 2$ as reductant. Hydrometallurgy 2006, 84, 187-191. [CrossRef]

24. Do, S.-H.; Batchelor, B.; Lee, H.-K.; Kong, S.-H. Hydrogen peroxide decomposition on manganese oxide (pyrolusite): Kinetics, intermediates, and mechanism. Chemosphere 2009, 75, 8-12.

25. Li, H.; Zhang, Z.; Tang, S.; Li, Y.; Zhang, Y. Ultrasonically assisted acid extraction of manganese from slag. Ultrason. Sonochem. 2008, 15, 339-343. [CrossRef]

26. Zhang, C.; Wang, S.; Cao, Z.-F.; Zhong, H. Two-stage leaching of manganese and silver from manganese-silver ores by reduction with calcium sulfide and oxidation with copper(II). Hydrometallurgy 2018, 175, 240-249. [CrossRef] 
27. Zhang, C.; Wang, S.; Cao, Z.-F.; Zhong, H. A novel process for the separation and recovery of value-added metals from manganese-silver ores by EDTA/EDTA-2Na and thiosulfate. Hydrometallurgy 2018, 178, $256-263$. [CrossRef]

28. Vu, H.; Jandova, J.; Lisa, K.; Vranka, F. Leaching of manganese deep ocean nodules in FeSO4-H2SO4-H2O solutions. Hydrometallurgy 2005, 77, 147-153. [CrossRef]

29. Chen, W.-S.; Liao, C.-T.; Lin, K.-Y. Recovery of Zinc and Manganese from Spent Battery Powder by Hydrometallurgical Route. Energy Procedia 2017, 107, 167-174.

30. Pagnanelli, F.; Furlani, G.; Valentini, P.; Veglio, F.; Toro, L. Leaching of low-grade manganese ores by using nitric acid and glucose: Optimization of the operating conditions. Hydrometallurgy 2004, 75, 157-167. [CrossRef]

31. Tian, Q.-H.; Jiao, C.-Y.; Guo, X.-Y. Extraction of valuable metals from manganese-silver ore. Hydrometallurgy 2012, 119-120, 8-15. [CrossRef]

32. Petrie, L.M. Molecular interpretation for $\mathrm{SO} 2$ dissolution kinetics of pyrolusite, manganite and hematite. Appl. Geochem. 1995, 10, 253-267. [CrossRef]

33. Kobylin, P.M.; Taskinen, P.A. Thermodynamic modelling of aqueous Mn(II) sulfate solutions. Calphad 2012, 38, 146-154. [CrossRef]

34. Field, T.B.; Coburn, J.; McCourt, J.L.; McBryde, W.A.E. Composition and stability of some metal citrate and diglycolate complexes in aqueous solution. Anal. Chim. Acta 1975, 74, 101-106. [CrossRef]

35. Meyer, J.L. Formation constants for interaction of citrate with calcium and magnesium lons. Anal. Biochem. 1974, 62, 295-300. [CrossRef]

36. Singh, R.P.; Yeboah, Y.D.; Pambid, E.R.; Debayle, P. Stability constant of the calcium-citrate(3-) ion pair complex. J. Chem. Eng. Data 1991, 36, 52-54. [CrossRef]

(C) 2020 by the authors. Licensee MDPI, Basel, Switzerland. This article is an open access article distributed under the terms and conditions of the Creative Commons Attribution (CC BY) license (http://creativecommons.org/licenses/by/4.0/). 